\title{
The Effect of Stress Perceived by Adults Due to the COVID-19 Pandemic on Their Sleep Quality
}

\author{
Yetișkinlerin COVID-19 Pandemisi Nedeni ile Algıladıkları Stresin Uyku Kalitesine \\ Etkisi
}

\author{
(D) Sebahat Atalıkoğlu Başkan, (D) Demet Güneş \\ Erzincan Binali Yıldırım University Faculty of Health Sciences, Department of Internal Medicine Nursing, Erzincan, Turkey
}

\begin{abstract}
Objective: Coronavirus disease-2019 (COVID-19) causes stress, anxiety, depression and sleep disturbance as well as common physical health problems. This study aimed to determine the effect of stress perceived by adults due to the COVID-19 pandemic on their sleep quality.

Materials and Methods: Using the snowball sampling method for sample selection, 1.909 individuals aged 18-65 years living in Turkey who agreed to participate in the research, were knowledgeable about the use of social media and were not diagnosed with any psychiatric disorders were included in this descriptive study. Data collection forms were uploaded online and published via Google Forms. The survey was conducted between 30 April and 10 May 2020. Sociodemographic information form, Perceived Stress scale (PSS) and Pittsburgh Sleep Quality index (PSQI) were used as data collection tools.

Results: The participants scored $15.58 \pm 5.16$ points in the perceived insufficient Self-Efficacy subscale, $15.20 \pm 5.41$ in the perceived stress/ distress subscale and $30.78 \pm 8.85$ in the total PSS. The PSQI score was $7.78 \pm 3.46$, and $71.6 \%$ of the participants had poor sleep quality. A significant, positive and weak relationship was found between the total scores on PSQI and PSS $(p<0.05)$.

Conclusion: Results of this study suggest that adults had higher perceived stress and poor sleep quality and their sleep quality decreases as the perceived stress increases during the COVID-19 pandemic.

Keywords: COVID-19, stress, sleep
\end{abstract}

Öz

Amaç: Koronavirüs hastalığı-2019 (COVID-19), yaygın fiziksel sağlık problemlerinin yanı sıra bireyde stres, anksiyete, depresyon ve uyku bozukluğuna neden olmaktadır. Çalışma, yetişkinlerin COVID-19 salgını nedeniyle algıladıkları stresin uyku kalitelerine etkisini belirlemek amacıyla yapıldı.

Gereç ve Yöntem: Tanımlayıcı tipte olan araştırmanın evrenini Türkiye'de yaşayan 18-65 yaş arası bireyler oluşturmuştur. Araştırmanın örneklem seçiminde kartopu örnekleme yönteminden yararlanarak araştırmaya katılmayı kabul eden, 18-65 yaş arasında olan, sosyal medya kullanmayı bilen, herhangi bir psikiyatrik bozukluk tanısı olmayan toplam 1,909 kişi yer almıştır. Araştırmada kullanılacak veri toplama formları online ortama aktarılarak Google form üzerinden yayınlanmıştır. Anket uygulaması, 30 Nisan-10 Mayıs 2020 tarihleri arasında yapılmışıtır. Araştırmada veri toplama aracı olarak sosyodemografik bilgi formu, Algılanan Stres ölçeği (ASÖ) ve Pittsburgh Uyku Kalitesi indeksi (PUKI) kullanılmıştır.

Bulgular: Katilımcılar yetersiz öz yeterlik algısı alt boyutundan $15,58 \pm 5,16$, stres/rahatsızlık algısı alt boyutundan $15,20 \pm 5,41$ ve ASÖ toplamından $30,78 \pm 8,85$ puan almışlardır. Katııımcıların PUKI toplam puanı 7,78 $\pm 3,46$ olup katılımcıların $\% 71,6^{\prime}$ sının uyku kalitesinin kötü olduğu belirlenmiștir. PUKI toplam puanı ile toplam ASÖ puanı arasında istatistiksel olarak anlamlı, pozitif yönlü ve düşük düzeyli ilişki saptanmıştır $(p<0,05)$.

Sonuç: Araştırma sonucunda yetişkinlerin COVID-19 pandemi sürecinde algıladıkları stresin yüksek, uyku kalitelerinin kötü olduğu ve algıladıkları stres artıkça uyku kalitelerinin azaldığı saptanmıştır.

Anahtar Kelimeler: COVID-19, stres, uyku

\section{Introduction}

As a major public health threat, coronavirus ( $\mathrm{CoV}$ ) is one of the microorganisms, such as Severe Acute Respiratory syndrome and Middle East Respiratory syndrome that targets the respiratory system and causes many diseases and deaths, and has the ability to infect humans by transmitting from animals (1). An outbreak of not fully known etiology that manifest itself with pneumonia was reported to have started in Wuhan city, Hubei Province, China in late December of 2019 (2). On March $11^{\text {th }}, 2020$, the World Health Organization (WHO) declared the CoV disease-2019 (COVID-19) outbreak caused

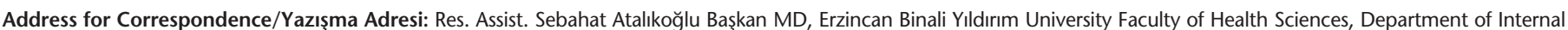
Medicine Nursing, Erzincan, Turkey Phone: +90 5308228324 E-mail: atalikoglu_sebahat@hotmail.com ORCID-ID: orcid.org/0000-0002-3656-7186 Received/Geliş Tarihi: 09.11.2020 Accepted/Kabul Tarihi: 27.01.2021

${ }^{\circ}$ Copyright 2021 by Turkish Sleep Medicine Society / Journal of Turkish Sleep Medicine published by Galenos Publishing House. 
by this virus as a pandemic (3). The COVID-19 disease can be seen in all age groups, and can lead to severe pneumonia, acute respiratory distress and mortality in the elderly and in individuals with chronic diseases, such as cardiovascular disease, diabetes, hypertension, respiratory disease, and malignancy (4). According to $\mathrm{WHO}$ data, the number of cases worldwide was 24,257 989, the number of deaths was 827,246, and the number of cases and deaths in Turkey were 262,507 and 6.183 , respectively, as of August $28^{\text {th }}, 2020$ (5). The infection is transmitted from symptomatic or asymptomatic individuals through inhalation of large droplets formed during coughing or sneezing, or by direct contact with the mouth, nose and eyes after touching contaminated surfaces (6). COVID-19 related symptoms are not specific, and the most common symptoms include fever, cough, shortness of breath and fatigue, in addition to sputum, headache, hemoptysis, diarrhea and lymphopenia $(7,8)$. There is no specific antiviral drug treatment or vaccine for COVID-19 infection, and the treatment focuses on symptomatic approach and respiratory support (1).

The COVID-19 disease poses a serious threat to mental health by causing stress, anxiety, depression as well as widespread physical health problems in the individuals leading to negative behavior in the community (9). The quarantine practices that impose lockdown, the restrictions on commuting to work, economic problems, disruptions in education, travel restrictions, social distancing, decrease in agricultural production, restrictions in the right to health care provision, fear of being infected and the fear of losing family members and loved ones cause psychological disorders, such as stress in individuals $(10,11)$. Stress, which is defined as non-apparent response to environmental stressors, affects the individuals' life, relationships with people and can cause problems in physical, social and mental areas $(12,13)$. Individuals may face numerous symptoms, such as sleep disturbance, irritability, concentration difficulties, anger, fatigue, palpitations, diarrhea, constipation, frequent urination, and headache as a result of an intensive and long-term stress (13). Sleep, which is closely associated with psychological disorders, is an important indicator of health. Sleep is a very important life activity for the vital functions of neural development, such as learning and memory, in the removal of cellular toxins, in the healthy functioning of the immune system, and in cardiovascular and metabolic regulation. Therefore, it is stated that quality sleep is essential to improve individuals' physical, social and spiritual well-being and quality of life $(14,15)$. The study was conducted to determine the effect of stress perceived by adults due to the COVID-19 pandemic on their sleep quality.

\section{Materials and Methods}

\section{Research design}

The present study is a descriptive type research.

\section{Study population and sampling}

The study population consisted of individuals in 18-65 age group living in Turkey. The snowball sampling method, which is one of the non-random sampling methods, was used in the sample selection of the study. The aim of snowball sampling method is to reach more comprehensive information in analyzing common situations by establishing contact with a person of this characteristic and then reaching others in chains with the help of this person (16). Using this sampling method, a total of 1.909 individuals in the 18-65 age group who agreed to participate in the research, who knew how to use social media, and who were not diagnosed with any psychiatric disorders was included in the sample of the study.

\section{Data collection}

Data collection forms used in the research were uploaded online and published via Google form. The link to this form was shared via social media platforms, and the form was asked to be filled out and distributed to other interested individuals. When preparing questions online, the "required field" option was selected, allowing participants to be notified by the system when questions are left blank. The survey was conducted between April $30^{\text {th }}$ and May $10^{\text {th }}, 22020$. Sociodemographic Information form, Perceived Stress scale (PSS), and Pittsburgh Sleep Quality index (PSQI) were used as data collection tools in the study.

\section{Sociodemographic information form}

The form developed by the researchers consists of questions on the participants' education, age, gender, occupation, marital status, chronic disease presence, etc.

\section{PSS}

Developed by Cohen et al. (17), the scale was adapted into Turkish by Eskin et al. (18) There are two sub-scales of the scale: perceived insufficient self-efficacy and perceived stress/ distress. The perceived insufficient Self-Efficacy subscale consists of the items numbered 4, 5, 6, 8, 9, 10, 13, and the perceived stress/distress sub-scale consists of the items numbered 1, 2, $3,7,11,12$, and 14. The Cronbach's alpha value of the scale was found to be 0.86 . Cronbach's alpha values of perceived insufficient self-efficacy and perceived stress/distress sub-scales were found to be 0.81 and 0.76 , respectively. On the scale, individuals are asked to rate how often they have experienced certain emotions or thoughts in the past month, by marking a point from 0 (never) to 4 (very often). The points taken from the items are added to determine the stress level perceived by the participants. PSS scores range from 0 to 56, and high scores indicate a high level of perceived stress. In this study, Cronbach's alpha values of the perceived insufficient selfefficacy and perceived stress/distress sub-scales were found as 0.83 and 0.79 , respectively, and the Cronbach's alpha of the PSS total was found as 0.84 .

\section{PSQI}

The scale developed by Ağargün et al. (19) was adapted into Turkish by Buysse et al. (20). PSQI is a 19-item self-report scale that assesses sleep quality and sleep disorder in the past months' time. It consists of 24 items, of which 19 items are self-report questions, and 5 of the items are questions to be answered by the spouse or roommate. The 18 items on the scale consist of 7 components: Subjective sleep quality, sleep latency, sleep 
duration, habitual sleep efficiency, sleep disturbances, use of sleeping medication, and daytime sleep dysfunction. Each item is scored in the range of $0-3$, and the total score of 7 items gives the scale total score. The total score ranges from 0 to 21 , and the total score greater than 5 indicates "poor sleep quality". The PSQI Cronbach's alpha value was 0.80 in this study.

\section{Statistical Analysis}

The data were analyzed using the SPSS for Windows 22 package program. In the analysis of the data, numbers, percentiles, minimum and maximum values, mean and standard deviations, as well as the independent samples t-test in measurements with normal distribution, analysis of variance, Pearson correlation analysis was used, and as an advanced analysis, least significant difference was used in case of homogeneous the variance, and Dunnet $C$ was used in case of non-homogeneous variance. In non-normal measurements, Mann-Whitney U test, KruskalWallis test, Spearman correlation analysis were used, and MannWhitney $U$ test was used for the advanced analysis. Skewness and Kurtosis coefficients were used to evaluate the normal distribution of the data.

\section{Ethical aspects of the study}

The conduct of the research, the ethics committee approval of a university in Turkey (approval of the ethics committee dated: 30/04/2020 and numbered: 04) and permission from the scientific research platform of the Turkish Ministry of Health was obtained. The individuals who volunteered to participate in the research were informed about the purpose of the research, and that the data obtained will be kept confidential and will not be shared with anyone.

\section{Results}

As shown in Table 1, 69\% of the respondents was female, $48.9 \%$ was married, $68.5 \%$ had moderate income, and $43.1 \%$ was a civil servant. Of the participants, $78.6 \%$ was university graduate, $41.4 \%$ was residing in a metropolitan city, $70.4 \%$ was not a smoker, and $84.1 \%$ did not have a chronic disease. Of the participants, $70.6 \%$ considers their own measures as adequate in relation to COVID-19, and $64.9 \%$ follows the developments about COVID-19 pandemic on TV or internet for 1-2 hours a day. The mean age of the participants was $31.93 \pm 9.76$, and they were living together with $3.83 \pm 1.63$ people on average (Table 1 ).

As shown in Table 2, the participants scored $15.58 \pm 5.16$ points in the Perceived Insufficient Self-Efficacy subscale, $15.20 \pm 5.41$ in the Perceived Stress/Distress sub-scale, and $30.78 \pm 8.85$ in the total PSS. The PSQI score was $7.78 \pm 3.46$ and $71.6 \%$ of the participants had poor sleep quality (Table 2).

As shown in Table 3, there were significant differences in the Perceived Insufficient Self-Efficacy and Perceived Stress/ Distress sub-scale scores, according to the gender, marital status, income status, occupation, educational status, smoking status, and consideration of the personal measures as adequate in relation to COVID-19 $(p<0.05)$. Perceived Insufficient SelfEfficacy score was found to be significant in terms of the presence of a chronic disease. The perceived stress/distress subscale score varies significantly according to the time (hours) to follow developments on COVID-19 per day $(p<0.05)$ (Table 3 ). The total PSS score varies significantly according to gender, marital status, occupation, educational status, smoking and presence of a chronic disease $(p<0.05)$. The mean scores were higher for single individuals and women. In advanced analysis, total PSS score averages were found to be higher among civil servants and students than workers, among university graduates than secondary school and high school graduates, and among those with respiratory system disease than those with endocrine or cardiovascular diseases. In addition, according to their smoking status, it was found that the total PSS score average of the participants who marked the response "smoker, there's been no change" was lower than the others (Table 3).

As shown in Table 3, the total PSS score did not differ significantly according to income status, place of residence, the consideration of the measures taken related to COVID-19 as adequate, and the duration to follow the developments on COVID-19 per day ( $p>0.05)$ (Table 3$)$.

There was a significant difference in the PSQI total score, according to participants' gender, marital status, income status, educational status, place of residence, smoking status, presence of chronic disease, consideration of their own measures against COVID-19 as adequate, and the duration of time to follow the developments related to COVID-19 $(p<0.05)$. The average score of females, singles and those who consider the measures taken in relation to COVID-19 as inadequate was higher. The total PSQI score according to the profession of the participants did not change significantly ( $p>0.05$ ) (Table 3 ).

In advanced analysis, the total PSQI score averages were found to be higher in those with poor and moderate level of income than those with good level of income, in university graduates than secondary school and high school graduates, in those living in a metropolitan city than those living in districts, in those having a respiratory disease than those with without a chronic disease and those with cardiovascular disease, and in those who watch the news on COVID-19 for at least 2 hours a day than those who watch the related developments less than 2 hours a day. In addition, according to their smoking status, it was determined that the total PSQI score average of the nonsmoker participants was lower than the others (Table 3).

As shown in Table 4, there was no significant relationship between age and Perceived Insufficient Self-Efficacy score ( $p>0.05)$. There was a statistically significant, negative and lowlevel relationship between age and perceived stress/distress sub-scale score, total PSS score, and total PSQI score $(p<0.05)$. As age increases, Perceived Stress/Distress sub-scale score, total PSS and PSQI scores decrease. There was a statistically significant, negative and low-level relationship between the number of people living together and the perceived Insufficient Self-Efficacy score, the total PSS score and the total PSQI score $(p<0.05)$. As the number of people living together increases, the Perceived Insufficient Self-Efficacy score, total PSS and PSQI scores decrease (Table 4). 


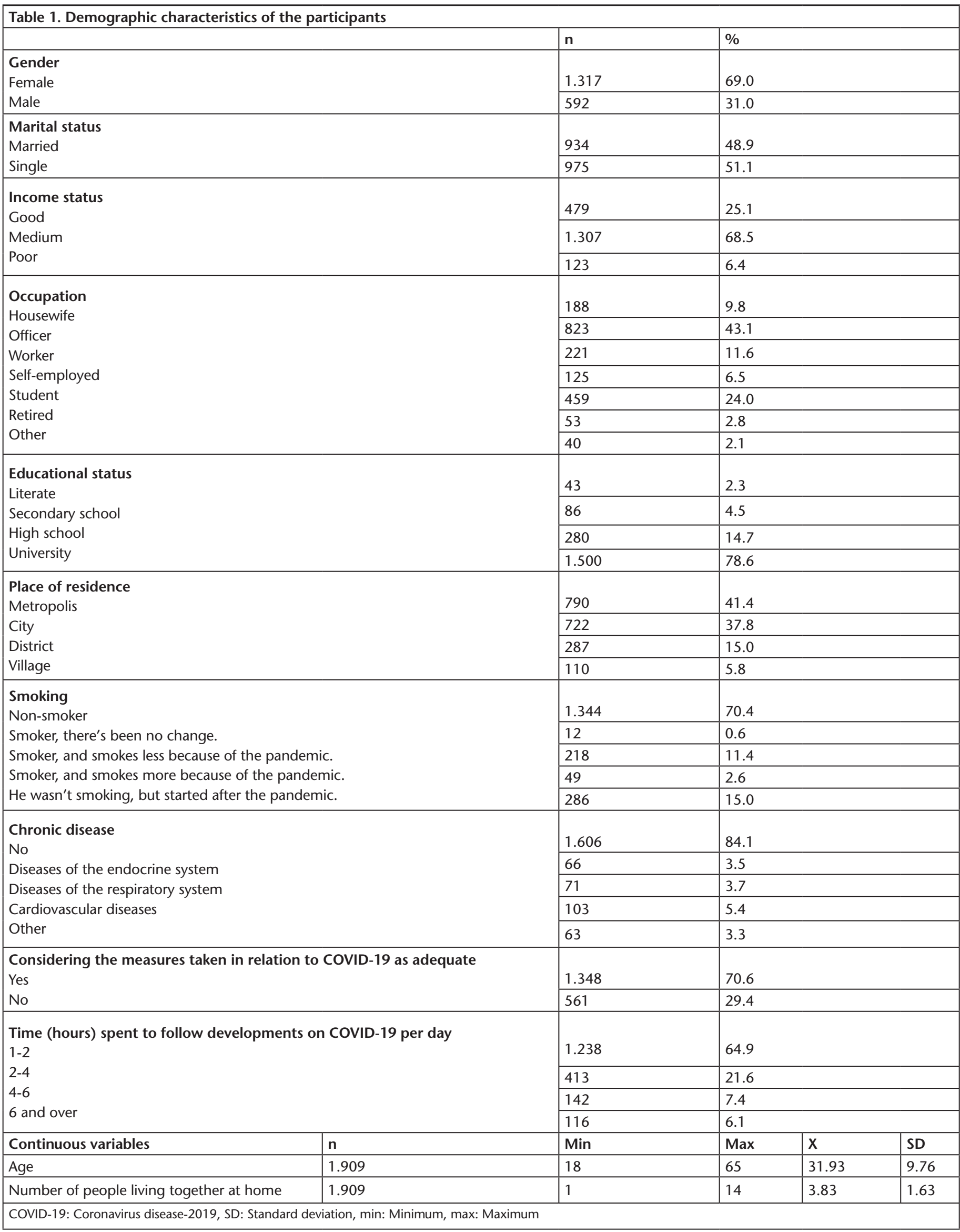




\begin{tabular}{|c|c|c|c|c|c|}
\hline Scales and Sub-scales & $\mathbf{n}$ & Min & Max & $\mathrm{x}$ & SD \\
\hline Perceived Stress scale & 1.909 & 0 & 56 & 30.78 & 8.85 \\
\hline Perceived Insufficient Self-Efficacy subscale & 1.909 & 0 & 28 & 15.58 & 5.16 \\
\hline Perceived Stress/Distress Sub-scale & 1.909 & 0 & 28 & 15.20 & 5.41 \\
\hline Pittsburgh Sleep Quality index & 1.909 & 1 & 20 & 7.78 & 3.46 \\
\hline PSQI Sleep Quality by scale cut-off points & $\mathbf{n}$ & $\%$ & - & - & - \\
\hline Good & 542 & 28.4 & - & - & - \\
\hline Poor & 1367 & 71.6 & - & - & - \\
\hline
\end{tabular}

\begin{tabular}{|c|c|c|c|c|c|}
\hline & \multirow[t]{2}{*}{$\mathbf{n}$} & $\begin{array}{l}\text { Insufficient } \\
\text { self-efficacy }\end{array}$ & Perceived stress/distress & Total PSS score & PSQI \\
\hline & & $X \pm S D$ & $X \pm S D$ & $X \pm S D$ & $X \pm S D$ \\
\hline \multicolumn{6}{|l|}{ Gender } \\
\hline Female & 1.317 & $15.81 \pm 4.78$ & $16.06 \pm 5.03$ & $31.87 \pm 8.01$ & $7.99 \pm 3.47$ \\
\hline Male & 592 & $15.06 \pm 5.90$ & $13.28 \pm 5.72$ & $28.34 \pm 10.07$ & $7.31 \pm 3.40$ \\
\hline \multicolumn{2}{|l|}{ Test and significance } & $\begin{array}{l}t=2.694 \\
p=0.007\end{array}$ & $\begin{array}{l}t=10.199 \\
p=0.000\end{array}$ & $\begin{array}{l}t=7.521 \\
p=0.000\end{array}$ & $\begin{array}{l}t=4.034 \\
p=0.000\end{array}$ \\
\hline \multicolumn{6}{|l|}{ Marital status } \\
\hline Married & 934 & $15.89 \pm 5.39$ & $14.47 \pm 5.43$ & $30.36 \pm 9.21$ & $7.57 \pm 3.52$ \\
\hline Single & 975 & $15.28 \pm 4.92$ & $15.90 \pm 5.30$ & $31.18 \pm 8.47$ & $7.98 \pm 3.39$ \\
\hline \multicolumn{2}{|l|}{ Test and significance } & $\begin{array}{l}t=2.592 \\
p=0.010\end{array}$ & $\begin{array}{l}t=-5.819 \\
p=0.000\end{array}$ & $\begin{array}{l}t=-2.017 \\
p=0.044\end{array}$ & $\begin{array}{l}t=-2.636 \\
p=0.008\end{array}$ \\
\hline \multicolumn{6}{|l|}{ Income status } \\
\hline Good & 479 & $16.03 \pm 5.55$ & $14.66 \pm 5.52$ & $30.69 \pm 9.33$ & $7.42 \pm 3.49$ \\
\hline Medium & 1.307 & $15.54 \pm 4.94$ & $15.35 \pm 5.27$ & $30.90 \pm 8.52$ & $7.85 \pm 3.44$ \\
\hline Poor & 123 & $14.13 \pm 5.64$ & $15.68 \pm 6.26$ & $29.81 \pm 10.23$ & $8.41 \pm 3.47$ \\
\hline \multicolumn{2}{|l|}{ Test and significance } & $\begin{array}{l}F=6.738 \\
p=0.001\end{array}$ & $\begin{array}{l}F=3.393 \\
p=0.034\end{array}$ & $\begin{array}{l}F=0.873 \\
p=0.418\end{array}$ & $\begin{array}{l}F=4.939 \\
p=0.007\end{array}$ \\
\hline \multicolumn{6}{|l|}{ Occupation } \\
\hline Housewife & 188 & $15.61 \pm 5.96$ & $14.44 \pm 5.82$ & $30.05 \pm 10.52$ & $7.44 \pm 3.40$ \\
\hline Officer & 823 & $16.22 \pm 4.70$ & $15.32 \pm 4.98$ & $31.54 \pm 7.80$ & $8.01 \pm 3.54$ \\
\hline Worker & 221 & $14.86 \pm 5.77$ & $13.98 \pm 5.91$ & $28.84 \pm 10.12$ & $7.27 \pm 3.44$ \\
\hline Self-employed & 125 & $15.20 \pm 6.04$ & $14.42 \pm 5.64$ & $29.62 \pm 10.28$ & $8.02 \pm 3.79$ \\
\hline Student & 459 & $14.89 \pm 4.92$ & $16.41 \pm 5.30$ & $31.30 \pm 8.56$ & $7.74 \pm 3.24$ \\
\hline Retired & 53 & $15.23 \pm 5.74$ & $12.81 \pm 5.94$ & $28.04 \pm 10.28$ & $7.51 \pm 3.48$ \\
\hline Other & 40 & $15.60 \pm 4.05$ & $14.7 \pm 85.52$ & $30.38 \pm 6.99$ & $7.58 \pm 3.35$ \\
\hline \multicolumn{2}{|l|}{ Test and significance } & $\begin{array}{l}F=4.383 \\
p=0.000\end{array}$ & $\begin{array}{l}F=8.769 \\
p=0.000\end{array}$ & $\begin{array}{l}F=4.527 \\
p=0.000\end{array}$ & $\begin{array}{l}F=1.910 \\
p=0.076\end{array}$ \\
\hline \multicolumn{6}{|l|}{ Educational status } \\
\hline Literate & 43 & $14.53 \pm 7.12$ & $12.40 \pm 5.81$ & $26.93 \pm 11.99$ & $6.84 \pm 3.26$ \\
\hline Secondary school & 86 & $12.95 \pm 6.59$ & $13.15 \pm 7.03$ & $26.10 \pm 12.38$ & $6.84 \pm 3.31$ \\
\hline High school & 280 & $14.12 \pm 6.03$ & $14.03 \pm 6.33$ & $28.15 \pm 11.06$ & $7.75 \pm 3.63$ \\
\hline University & 1.500 & $16.03 \pm 4.71$ & $15.62 \pm 5.01$ & $31.64 \pm 7.78$ & $7.87 \pm 3.44$ \\
\hline
\end{tabular}


Table 3. contiuned

\begin{tabular}{|c|c|c|c|c|c|}
\hline \multicolumn{2}{|l|}{ Test and significance } & $\begin{array}{l}F=19.829 \\
p=0.000\end{array}$ & $\begin{array}{l}F=15.684 \\
p=0.000\end{array}$ & $\begin{array}{l}F=24.640 \\
p=0.000\end{array}$ & $\begin{array}{l}F=3.522 \\
p=0.014\end{array}$ \\
\hline \multicolumn{6}{|l|}{ Place of residence } \\
\hline Metropolis & 790 & $15.59 \pm 4.99$ & $15.42 \pm 5.31$ & $31.01 \pm 8.42$ & $8.06 \pm 3.42$ \\
\hline City & 722 & $15.74 \pm 5.14$ & $15.05 \pm 5.42$ & $30.79 \pm 8.89$ & $7.75 \pm 3.57$ \\
\hline District & 287 & $15.38 \pm 5.63$ & $14.89 \pm 5.57$ & $30.26 \pm 9.76$ & $7.27 \pm 3.37$ \\
\hline Village & 110 & $14.89 \pm 5.25$ & $15.41 \pm 5.57$ & $30.30 \pm 9.13$ & $7.33 \pm 3.08$ \\
\hline \multicolumn{2}{|l|}{ Test and significance } & $\begin{array}{l}F=1.029 \\
p=0.379\end{array}$ & $\begin{array}{l}F=1.000 \\
p=0.392\end{array}$ & $\begin{array}{l}F=0.614 \\
p=0.606\end{array}$ & $\begin{array}{l}F=4.470 \\
p=0.004\end{array}$ \\
\hline \multicolumn{6}{|l|}{ Smoking } \\
\hline Non-smoker & 1.344 & $15.69 \pm 5.05$ & $15.35 \pm 5.30$ & $31.04 \pm 8.64$ & $7.53 \pm 3.38$ \\
\hline $\begin{array}{l}\text { Smoker, there's been no } \\
\text { change. }\end{array}$ & 12 & $11.33 \pm 5.09$ & $13.25 \pm 6.69$ & $24.58 \pm 11.53$ & $9.33 \pm 4.33$ \\
\hline $\begin{array}{l}\text { Smoker, and smokes less } \\
\text { because of the pandemic. }\end{array}$ & 218 & $15.14 \pm 5.24$ & $15.06 \pm 5.50$ & $30.20 \pm 8.97$ & $8.30 \pm 3.37$ \\
\hline $\begin{array}{l}\text { Smoker, and smokes more } \\
\text { because of the pandemic. }\end{array}$ & 49 & $14.65 \pm 6.01$ & $17.82 \pm 5.66$ & $32.47 \pm 9.28$ & $9.84 \pm 4.11$ \\
\hline $\begin{array}{l}\text { He wasn't smoking, but started } \\
\text { after the pandemic. }\end{array}$ & 286 & $15.68 \pm 5.40$ & $14.26 \pm 5.55$ & $29.94 \pm 9.40$ & $8.14 \pm 3.56$ \\
\hline \multicolumn{2}{|l|}{ Test and significance } & $\begin{array}{l}F=3.023 \\
p=0.017\end{array}$ & $\begin{array}{l}F=5.787 \\
p=0.000\end{array}$ & $\begin{array}{l}F=3.110 \\
p=0.015\end{array}$ & $\begin{array}{l}F=8.806 \\
p=0.000\end{array}$ \\
\hline \multicolumn{6}{|l|}{ Chronic disease } \\
\hline No & 1.606 & $15.56 \pm 5.14$ & $15.12 \pm 5.32$ & $30.67 \pm 8.78$ & $7.68 \pm 3.45$ \\
\hline $\begin{array}{l}\text { Diseases of the endocrine } \\
\text { system }\end{array}$ & 66 & $14.92 \pm 5.60$ & $15.98 \pm 6.55$ & $30.91 \pm 10.95$ & $8.92 \pm 3.64$ \\
\hline $\begin{array}{l}\text { Diseases of the respiratory } \\
\text { system }\end{array}$ & 71 & $17.39 \pm 3.54$ & $16.62 \pm 4.61$ & $34.01 \pm 5.69$ & $9.08 \pm 3.07$ \\
\hline Cardiovascular diseases & 103 & $14.94 \pm 5.69$ & $14.93 \pm 6.04$ & $29.87 \pm 9.36$ & $7.48 \pm 3.39$ \\
\hline Other & 63 & $15.75 \pm 5.47$ & $15.35 \pm 5.92$ & $31.10 \pm 9.79$ & $8.17 \pm 3.71$ \\
\hline \multicolumn{2}{|l|}{ Test and significance } & $\begin{array}{l}F=2.890 \\
p=0.021\end{array}$ & $\begin{array}{l}F=1.744 \\
p=0.138\end{array}$ & $\begin{array}{l}F=2.734 \\
p=0.028\end{array}$ & $\begin{array}{l}F=5.106 \\
p=0.000\end{array}$ \\
\hline \multicolumn{6}{|c|}{ Considering the measures as adequate in relation to COVID-19 } \\
\hline Yes & 1.348 & $15.90 \pm 5.19$ & $14.84 \pm 5.34$ & $30.74 \pm 8.92$ & $7.47 \pm 3.39$ \\
\hline No & 561 & $14.80 \pm 5.02$ & $16.06 \pm 5.47$ & $30.86 \pm 8.68$ & $8.53 \pm 3.51$ \\
\hline \multicolumn{2}{|l|}{ Test and significance } & $\begin{array}{l}t=4.231 \\
p=0.000\end{array}$ & $\begin{array}{l}t=-4.486 \\
p=0.000\end{array}$ & $\begin{array}{l}t=-0.271 \\
p=0.786\end{array}$ & $\begin{array}{l}t=-6.142 \\
p=0.000\end{array}$ \\
\hline \multicolumn{6}{|c|}{ Ti me (hours) spent to follow developments on COVID-19 per day } \\
\hline $1-2$ & 1.238 & $15.81 \pm 5.07$ & $14.76 \pm 5.23$ & $30.57 \pm 8.53$ & $7.41 \pm 3.34$ \\
\hline $2-4$ & 413 & $15.05 \pm 5.21$ & $15.86 \pm 5.62$ & $30.92 \pm 9.24$ & $8.38 \pm 3.54$ \\
\hline $4-6$ & 142 & $15.39 \pm 4.87$ & $16.37 \pm 4.99$ & $31.75 \pm 8.39$ & $8.72 \pm 3.39$ \\
\hline 6 and over & 116 & $15.16 \pm 6.12$ & $16.11 \pm 6.44$ & $31.28 \pm 11.09$ & $8.49 \pm 3.91$ \\
\hline \multicolumn{2}{|l|}{ Test and significance } & $\begin{array}{l}F=2.572 \\
p=0.053\end{array}$ & $\begin{array}{l}F=8.177 \\
p=0.000\end{array}$ & $\begin{array}{l}F=0.958 \\
p=0.412\end{array}$ & $\begin{array}{l}F=14.241 \\
p=0.000\end{array}$ \\
\hline
\end{tabular}


A statistically significant, positive and weak relationship was found between the PSQI total score and the Perceived Stress/ Distress score and total PSS score $(p<0.05)$. As the PSQI total score increases, the Perceived Stress/Distress and the total PSS score also increases. No significant relationship was found between PSQI total score and Perceived Insufficient Self-Efficacy score (Table 5).

\section{Discussion}

Although the COVID-19 outbreak, which has been declared a pandemic, has been tried to be controlled by the authorities, the rapid spread of the virus and the difficulties in the clinical process make it difficult to fight against this outbreak. Factors such as uncertainty in diagnosis and treatment in CoV outbreak, high risk and mortality rates, and social isolation cause stress in individuals. The stress experienced first affects the immune system in individuals and causes psychological, social and physiological negative consequences (21).

In addition, sleep disorder, which is one of the psychological responses to stressors, has a serious impact on the daily lives of individuals (13).

The study found that adults had a high level of perceived stress due to the COVID-19 pandemic. In parallel to our findings, the studies on the COVID-19 pandemic also indicated high levels

\begin{tabular}{|l|l|l|l|}
\hline \multicolumn{3}{|l|}{$\begin{array}{l}\text { Table 4. Investigation of the relationship between age, number of } \\
\text { people living together and PSQI and PSS total and Sub-scale scores }\end{array}$} \\
\hline \multirow{4}{*}{} & \multicolumn{1}{|l}{ Age } & $\begin{array}{l}\text { Number of } \\
\text { people living } \\
\text { together at } \\
\text { home }\end{array}$ \\
\hline \multirow{4}{*}{ Insufficient self-efficacy } & $\mathrm{r}$ & 0.024 & -0.101 \\
\cline { 2 - 4 } & $\mathrm{p}$ & 0.303 & $\mathbf{0 . 0 0 0}$ \\
\cline { 2 - 4 } & $\mathrm{n}$ & 1.909 & 1.909 \\
\hline \multirow{4}{*}{ Perceived stress/distress } & $\mathrm{r}$ & -0.196 & -0.013 \\
\cline { 2 - 4 } & $\mathrm{p}$ & $\mathbf{0 . 0 0 0}$ & 0.571 \\
\cline { 2 - 4 } & $\mathrm{n}$ & 1.909 & 1.909 \\
\hline \multirow{4}{*}{ Total PSS score } & $\mathrm{r}$ & -0.106 & -0.067 \\
\cline { 2 - 4 } & $\mathrm{p}$ & $\mathbf{0 . 0 0 0}$ & $\mathbf{0 . 0 0 4}$ \\
\cline { 2 - 4 } & $\mathrm{n}$ & 1.909 & 1.909 \\
\hline \multirow{4}{*}{ Total PSQI score } & $\mathrm{r}$ & -0.072 & -0.053 \\
\cline { 2 - 4 } & $\mathrm{p}$ & $\mathbf{0 . 0 0 2}$ & $\mathbf{0 . 0 2 2}$ \\
\cline { 2 - 4 } & $\mathrm{n}$ & 1.909 & 1.909 \\
\hline PSQI: Pittsburgh Sleep Quality index, $\mathrm{PSS}:$ Perceived Stress scale \\
\hline
\end{tabular}

Table 5. Investigation of the relationship between the PSS and PSQI

\begin{tabular}{|l|l|l|l|l|}
\hline \multicolumn{2}{|c|}{} & $\begin{array}{l}\text { Insufficient } \\
\text { self-efficacy }\end{array}$ & $\begin{array}{l}\text { Perceived } \\
\text { stress/ } \\
\text { distress }\end{array}$ & $\begin{array}{l}\text { Total PSS } \\
\text { score }\end{array}$ \\
\hline \multirow{3}{*}{$\begin{array}{l}\text { PSQI total } \\
\text { score }\end{array}$} & $\mathrm{r}$ & -0.042 & 0.401 & 0.220 \\
\cline { 2 - 5 } & $\mathrm{p}$ & 0.064 & $\mathbf{0 . 0 0 0}$ & $\mathbf{0 . 0 0 0}$ \\
\cline { 2 - 5 } & $\mathrm{n}$ & 1.909 & 1.909 & 1.909 \\
\hline \multicolumn{3}{|l|}{ PSQI: Pittsburgh Sleep Quality index, PSS: Perceived Stress scale } \\
\hline
\end{tabular}

PSQI: Pittsburgh Sleep Quality index, PSS: Perceived Stress scale of stress $(22,23)$. In other studies, related to the COVID-19 pandemic, however, stress was found to be moderate (24-27). In the study, it was found that the gender, marital status, occupation and the presence of chronic disease of the participants affected the stress they perceived as a result of the COVID-19 pandemic. Among the participants, women, singles, civil servants, students, and those with a chronic respiratory disease were found to have higher perceived stress. Similar to our research findings, in their study of the COVID-19 pandemic, Wang et al. (26) found that women, students and those with chronic diseases had higher perceived stress, while the marital status of the participants was not found to affect the perceived stress. Another study concluded that the stress level of women was higher during the COVID-19 pandemic, and that the marital status and occupation of the participants did not affect the level of stress (28). The decision to continue the education and training through distance education as a first precaution at the onset of the COVID-19 outbreak in Turkey, and the uncertainty in academic procedures are believed to affected students' mental health and increased their level of stress. It is also believed that perceived stress of those with a respiratoryrelated chronic disease has increased due to the news in the media stating that COVID-19 disease usually manifests itself with upper respiratory tract symptoms, has a high mortality potential, and that individuals with respiratory disease would likely be more affected by the disease. The meaning attributed by women to the stressor, their physiological characteristics, different hormone levels are believed to affect the physiological responses that occur with stress, and that higher social and personal expectations of women may increase their perceived stress.

The perceived stress was found to decrease with increasing age and increasing number of people living together at home. In line with our findings, many studies found that the perceived stress of the young adult group was higher $(23,29,30)$. The study by Mazza et al. (28) also concluded that perceived stress levels were high in the young adult group, and that the number of people living together at home did not affect perceived stress. In another study, no correlation was found between stress, age, and the number of people that live together (26). It is thought that social support can be effective in psychosocial adjustment and coping with highly probable symptoms that may occur with advanced age, and that higher use of social media in the young adult group and their ability to access more information regarding the COVID-19 pandemic may further trigger stress.

In the study, it was found that the educational status of the participants affected perceived stress and that the perceived stress of those who graduated from university was higher than secondary school or high school graduates. In parallel to our study, similar results have also been obtained in one study (31). People with higher education are believed to experience more stress due to the greater health awareness.

Sleep disorders in individuals experiencing stress affect the holistic well-being of individuals as well as lead to a decrease in the quality of life. In this study, $71.6 \%$ of the participants had poor sleep quality. Similar to our findings, many studies of 
the COVID-19 pandemic also found that participants had poor sleep quality $(14,32)$.

In the study, it was found that participants' gender, marital status, educational status, presence of a chronic disease and duration of following-up developments about COVID-19 affected their sleep quality during the COVID-19 pandemic. The women, singles, university graduates, those with chronic respiratory disease, those who followed the developments in COVID-19 for at least 2 hours a day were found to have poor sleep quality compared to other groups. In their study, Li et al. (33) found that education status and gender affect sleep quality, while marital status does not. Another study found that gender and the time spent in watching COVID-19-related developments per day did not affect sleep quality (32).

In this study, which was conducted during the COVID-19 pandemic, it was found that adults' sleep quality increases with increasing age and increasing number of people living together at home. Similar to our finding, it was stated in the literature that adequate social support has a positive effect on psychological health and sleep function $(34,35)$. The studies also found that the sleep quality of young adults was poor compared to other groups $(36,37)$.

Many restrictions imposed by authorities due to the COVID19 pandemic lead to unexpected stressful conditions in most individuals. This resulting stress can not only affect the mood of individuals, but can also cause a sleep disorder. Our research also found that sleep quality decreases as the perceived stress increases. A study in China has demonstrated that reducing widespread stress can help improve individuals' sleep quality (14). It is believed that the stress response to COVID-19 may lead to physical dysfunction, which may include sleep dysfunction (38). A meta-analysis study also stated that stress is among the common psychological reactions in the COVID-19 pandemic and may be associated with sleep disturbances (39). The findings of the other studies are also in line with the finding in this study $(14,40,41)$. It is believed that the fact that CoV causes dysfunction in many systems, especially in the immune system and respiratory system, creates a serious source of stress in individuals, leading to the sleep disorder.

\section{Study Limitations}

In the study, participants were reached by the snowball sampling method due to time constraints and to reduce the infection possibility of the researchers and participants during the COVID-19 outbreak. The psychosocial conditions of the participants prior to the pandemic process were not evaluated. Despite the limitations in the research, this study provides valuable and generalizable information about the psychosocial status of participants, since it was conducted during the period when the incidence of COVID-19 cases was the highest and many restrictions were imposed by the authorities in Turkey.

\section{Conclusion}

As a result of the study, it was found that adults had a high perceived stress and poor sleep quality during the COVID-19 pandemic. It was found that the gender, education and marital status, and the presence of a chronic disease of the adults affected the stress and sleep quality they perceived as a result of the COVID-19 pandemic. The participants' sleep quality was found to decrease as the stress they perceived increases due to the COVID-19 pandemic. In line with these results, it may be recommended to use online services to improve psychosocial conditions and sleep quality during the pandemic in particular, and to develop practices to adopt various strategies to help the public cope with stress in times of crisis.

\section{Implications for Nursing Practice}

Stress and sleep disturbance that occur during the pandemic process affect adults' daily activities. As stated in our research, it was concluded that adults have high stress levels and poor sleep quality during the pandemic process. In this process, it should be ensured that the necessary use is directed towards the use of psychological support units in order to ensure the use of services to increase the quality of psychosocial and sleep, and to cope with stress during the crisis.

\section{Ethics}

Ethics Committee Approval: The conduct of the research, the Ethics Committee Approval of a university in Turkey (approval of the Ethics Committee dated: 30/04/2020 and numbered: 04) and permission from the scientific research platform of the Turkish Ministry of Health was obtained.

Informed Consent: The individuals who volunteered to participate in the research were informed about the purpose of the research, and that the data obtained will be kept confidential and will not be shared with anyone.

Peer-review: Internally peer-reviewed.

\section{Authorship Contributions}

Concept: S.A.B., D.G., Design: S.A.B., D.G., Data Collection or Processing: S.A.B., D.G., Analysis or Interpretation: S.A.B., D.G., Literature Search: S.A.B., D.G., Writing: S.A.B., D.G.

Conflict of Interest: No conflict of interest was declared by the authors.

Financial Disclosure: The authors declared that this study received no financial support.

\section{References}

1. Rothan HA, Byrareddy SN. The epidemiology and pathogenesis of coronavirus disease (COVID-19) outbreak. J Autoimmun 2020;109:102433.

2. Huang C, Wang Y, Li X, Ren L, Zhao J, Hu Y, Zhang L, Fan G, Xu J, Gu X, Cheng Z, Yu T, Xia J, Wei Y, Wu W, Xie X,Yin W, Li H, Liu M, Xiao Y, Gao H, Guo L, Xie J, Wang G, Jiang R, Gao Z, Jin Q, Wang J, Cao B. Clinical features of patients infected with 2019 novel coronavirus in Wuhan, China. Lancet 2020;395:497-506.

3. Coronavirus disease (COVID-19) pandemic [Internet]. 2020 [cited 2020 May 8]. Available from: https://www.who.xn--int-8dc/ Emergencies/Diseases/Novel-Coronavirus-2019

4. Bansal $P$, Bingemann TA, Greenhawt $M$, Mosnaim G, Nanda A, Oppenheimer J, Sharma H, Stukus D, Shaker M. Clinician wellness during the COVID-19 pandemic: Extraordinary times and unusual challenges for the allergist/Immunologist. J Allergy Clin Immunol Pract 2020;8:1781-90. 
5. WHO Coronavirus Disease (COVID-19) Dashboard [Internet]. 2020. Available from: https://covid19.who.int/region/euro/country/tr

6. Kurtaiş Aytür $Y$, Köseoğlu BF, Özyemişçi Taşkıran Ö, Kutay OrduGökkaya N, Ünsal Delialioğlu S, Sonel Tur B, Sarıkaya S, Şirzai H, Tekdemir Tiftik T, Alemdaroğlu E, Ayhan FF, Duyur Çakıt B, Genç A, Gündoğdu I, Güzel R, Karayel DD, Kaya BB, Öken Ö, Özdemir H, Soyupek F, Tıkız C. Pulmonary rehabilitation principles after SarsCov-2 (Covid-19): Guide for management of the acute and subacute process 2020;66:104-20.

7. Wang W, Tang J, Wei F. Updated understanding of the outbreak of 2019 novel coronavirus (2019-nCoV) in Wuhan, China. J Med Virol 2020;92:441-7.

8. Li Q, Guan X, Wu P, Wang X, Zhou L, Tong Y, Ren R, Leung KSM, Lau EHY, Wong JY, Xing X, Xiang N, Wu Y, Li C, Chen Q, Li D, Liu T, Zhao J, Liu M, Tu W, Chen C, Jin L, Yang R, Wang Q, Zhou S, Wang R, Liu H, Luo Y, Liu Y, Shao G, Li H, Tao Z, Yang Y, Deng Z, Liu B, Ma Z, Zhang Y, Shi G, Lam TTY, Wu JT, Gao GF, Cowling BJ, Yang B, Leung GM, Feng Z. Early transmission dynamics in wuhan, china, of novel coronavirus-infected pneumonia. N Engl J Med 2020;382:1199-207.

9. Liu S, Yang L, Zhang C, Xiang Y-T, Liu Z, Hu S, Zhang B. Online mental health services in China during the COVID-19 outbreak. Lancet Psychiatry. 2020;7:e17-8. doi: 10.1016/S2215-0366(20)30077-8.

10. Fardin MA. COVID-19 and anxiety: A review of psychological impacts of infectious disease outbreaks. Arch Clin Infect Dis. 2020;15:e102779. doi: 10.5812/archcid.102779.

11. Üstün Ç, Özçiftçi S. Effects of COVID-19 pandemic on social life and ethical plane : An evaluation study. Anadolu Klin Tıp Bilim Derg 2020;142-53.

12. Kyle SD, Morgan K, Espie CA. Insomnia and health-related quality of life. Sleep Med Rev 2010;14:69-82.

13. Özel Y, Bay Karabulut A. Daily living and stress management. 2018;1:48-56.

14. Xiao H, Zhang Y, Kong D, Li S, Yang N. The effects of social support on sleep quality of medical staff treating patients with coronavirus disease 2019(COVID-19) in January and February 2020 in China. Med Sci Monit 2020;26:e923549. doi: 10.12659/MSM.923549.

15. Mukherjee S, Patel SR, Kales SN, Ayas NT, Strohl KP, Gozal D, Malhotra A, American Thoracic Society ad hoc Committee on Healthy Sleep. An official american thoracic society statement: The importance of healthy sleep. Recommendations and future priorities. Am J Respir Crit Care Med 2015;191:1450-8.

16. Kılıç S. Sampling methods. J Mood Disord 2013;3:44.

17. Cohen S, Kamarck T, Mermelstein R. A global measure of perceived stress. J Health Soc Behav 1983;24:385-96.

18. Eskin M, Harlak H, Demirkıran F, Dereboy Ç. The adaptation of the perceived stress scale into Turkish: A reliability and validity analysis. 2013;51:132-40.

19. Ağargün MY, Kara $H$, Anlar Ö. The validity and reliability of the pittsburgh sleep quality index. Turkish J Psychiatry 1996;7:107-11.

20. Buysse DJ, Reynolds CF, Monk TH, Berman SR, Kupfer DJ. The Pittsburgh sleep quality index: A new instrument for psychiatric practice and research. Psychiatry Res 1989;28:193-213.

21. Psychiatric association of Turkey preventive, preventive and therapeutic psychiatric services in covid-19treatment [Internet]. 2020. Available from: https://www.psikiyatri.org.tr/Tpddata/Uploads/Files/ Covid19_Pandemi_Psikiyatriktedavilertpdrtacb-05052020.Pdf
22. Wu W, Zhang Y, Wang P, Zhang L, Wang G, Lei G, Xiao Q, Cao X, Bian Y, Xie S, Huang F, Luo N, Zhang J, Luo M. Psychological stress of medical staffs during outbreak of COVID-19 and adjustment strategy. J Med Virol 2020;92:1962-70.

23. Park $C L$, Russell BS, Fendrich $M$, Finkelstein-Fox $L$, Hutchison $M$, Becker J. Americans' COVID-19 stress, coping, and adherence to CDC guidelines. J Gen Intern Med 2020;35:2296-303.

24. Umucu E, Lee B. Examining the impact of COVID-19 on stress and coping strategies in individuals with disabilities and chronic conditions. Rehabil Psychol 2020;65:193-8.

25. Xiao H, Zhang Y, Kong D, Li S, Yang N. Social capital and sleep quality in individuals who self-isolated for 14 days during the coronavirus disease 2019 (COVID-19) outbreak in january 2020 in China. Med Sci Monit 2020;26:e923921. doi: 10.12659/MSM.923921.

26. Wang C, Pan R, Wan X, Tan Y, Xu L, Ho CS, Ho RC. Immediate psychological responses and associated factors during the initial stage of the 2019 coronavirus disease (COVID-19) epidemic among the general population in China. Int J Environ Res Public Health 2020;17:1729.

27. Liang L, Ren H, Cao R, Hu Y, Qin Z, Li C, Mei S. The effect of COVID-19 on youth mental health. Psychiatr Q 2020;91:841-52.

28. Mazza C, Ricci E, Biondi S, Colasanti M, Ferracuti S, Napoli C, Roma P. A nationwide survey of psychological distress among italian people during the COVID-19 pandemic: Immediate psychological responses and associated factors. Int J Environ Res Public Health 2020;17:3165.

29. Qiu J, Shen B, Zhao M, Wang Z, Xie B, Xu Y. A nationwide survey of psychological distress among Chinese people in the COVID-19 epidemic: implications and policy recommendations. Gen Psychiatry 2020;33:e100213. doi: 10.1136/gpsych-2020-100213.

30. Ozamiz-Etxebarria N, Dosil-Santamaria M, Picaza-Gorrochategui M, Idoiaga-Mondragon N. Niveles de estrés, ansiedad y depresión en la primera fase del brote del COVID-19 en una muestra recogida en el norte de España. Cad Saude Publica [Internet]. 2020;36:e00054020. doi:10.1590/0102-311×00054020.http://www.scielo.br/scielo. php?script=sci_arttext\&pid=S0102-311X2020000405013\&tlng=es

31. Roberts T, Miguel Esponda G, Krupchanka D, Shidhaye R, Patel $\mathrm{V}$, Rathod S. Factors associated with health service utilisation for common mental disorders: a systematic review. BMC Psychiatry 2018;18:262.

32. Huang Y, Zhao N. Generalized anxiety disorder, depressive symptoms and sleep quality during COVID-19 outbreak in China: a web-based cross-sectional survey. Psychiatry Res 2020;288:112954.

33. Li X, Yu H, Bian G, Hu Z, Liu X, Zhou Q, Yu C, Wu X, Yuan TF, Zhoua D. Prevalence, risk factors, and clinical correlates of insomnia in volunteer and at home medical staff during the COVID-19. Brain Behav Immun 2020;87:140-1.

34. Prati G, Pietrantoni L. The relation of perceived and received social support to mental health among first responders: a meta-analytic review. J Community Psychol 2010;38:403-17.

35. Kent de Grey RG, Uchino BN, Trettevik R, Cronan S, Hogan JN. Social support and sleep: A meta-analysis. Heal Psychol 2018;37:787-98.

36. Yuan S, Liao Z, Huang $H$, Jiang $B$, Zhang $X$, Wang $Y$, Zhao $M$. Comparison of the indicators of psychological stress in the population of hubei province and non-endemic provinces in china during two weeks during the coronavirus disease 2019 (COVID-19) Outbreak in February 2020. Med Sci Monit 2020;26:e923767. doi: 10.12659/ MSM.923767. 
37. Wang S, Xie L, Xu Y, Yu S, Yao B, Xiang D. Sleep disturbances among medical workers during the outbreak of COVID-2019. Occup Med (Lond) 2020;70:364-9.

38. Duric V, Clayton S, Leong ML, Yuan LL. Comorbidity factors and brain mechanisms linking chronic stress and systemic illness. Neural Plast 2016;2016:1-16.

39. Rajkumar RP. COVID-19 and mental health: A review of the existing literature. Asian J Psychiatr 2020;52:102066.

40. Chew NWS, Lee GKH, Tan BYQ, Jing M, Goh Y, Ngiam NJH, Yeo LLL, Ahmad A, Khan FA, Shanmugam GN, Sharma AK, Komalkumar
RN, Meenakshi PV, Shah K, Patel B, Chan BPL, Sunny S, Chandra B, Ong JJY, Paliwal PR, Wong LYH, Sagayanathan R, Chen JT, Ng AYY, Teoh HL, Tsivgoulis G, Ho CS, Ho RC, Sharma VK. A multinational, multicentre study on the psychological outcomes and associated physical symptoms amongst healthcare workers during COVID-19 outbreak. Brain Behav Immun 2020;88:559-65.

41. Liu N, Zhang F, Wei C, Jia Y, Shang Z, Sun L, Wu L, Sun Z, Zhou Y, Wang Y, Liu W. Prevalence and predictors of PTSS during COVID-19 outbreak in China hardest-hit areas: Gender differences matter. Psychiatry Res 2020;287:112921. 